Wongkattiya et al., Afr J Tradit Complement Altern Med., (2018) 15 (2): 12-18

https://doi.org/10.21010/ajtcam.v15i2.2

\title{
CHEMICAL COMPOSITIONS AND BIOLOGICAL PROPERTIES OF ESSENTIAL OILS FROM ZANTHOXYLUM RHETSA (ROXB.) DC AND ZANTHOXYLUM LIMONELLA ALSTON
}

\section{Nalin Wongkattiya ${ }^{1}$, Chareeporn Akekawatchai ${ }^{2}$, Phanchana Sanguansermsri ${ }^{3}$, Ian Hamilton Fraser $^{4}$, Chayanin Pratoomsoot ${ }^{5}$, Donruedee Sanguansermsri ${ }^{6,7 *}$}

${ }^{1}$ Program in Biotechnology, Faculty of Science, Maejo University, Chiang Mai, Thailand; ${ }^{2}$ Department of Medical Technology, Faculty of Allied Health Sciences, Thammasat University, Pathumthani, Thailand; ${ }^{3}$ Department of Biochemistry, Faculty of Medical Science, Naresuan University, Phitsanulok, Thailand; ${ }^{4}$ School of Chemistry, Monash University, Clayton, Victoria 3800, Australia; ${ }^{5}$ Division of Applied Thai Traditional Medicine, Faculty of Public Health, Naresuan University, Phitsanulok, Thailand; ${ }^{6}$ Faculty of Medical Science, Naresuan University, Phitsanulok, Thailand; ${ }^{7}$ Centre of Excellence in Medical Biotechnology, Faculty of Medical Science, Naresuan University, Phitsanulok, Thailand.

*Corresponding Author Email: donruedees@ @u.ac.th ; donruedees@ hotmail.com

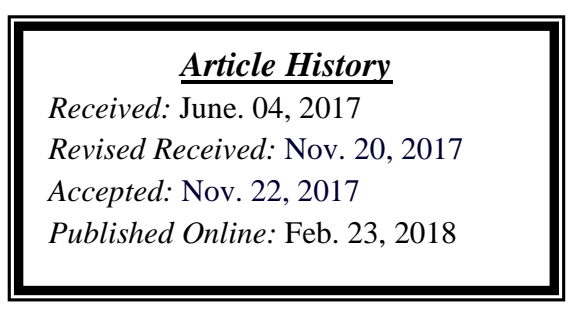

\section{Abstract}

Background: Zanthoxylum rhetsa (Roxb.) DC and Zanthoxylum limonella Alston are spices for flavouring in indigenous Thai food. They are traditionally used as an aromatic, astringent, antimicrobial, antiseptic and antidiabetic agent. The purpose of this study is to examine their chemical compositions and evaluate antibacterial, antioxidant and anticancer properties of the essential oils.

Materials and Methods: The essential oils of Z. rhetsa and Z. limonella were analysed for phytochemical constituents by Gas chromatography-mass spectrometry (GC-MS). The antibacterial activity was determined against several bacteria using the microdilution method. Antioxidant capacity was determined by free radical scavenger 2, 2-diphenyl1-picrylhydrazyl (DPPH) and 2, 2-azinobis-3-ethyl-benzothiazoline-6-sulfonic acid (ABTS) methods. The anticancer activity was determined with two breast cancer cell lines (MCF-7 and MDA-MB-231) and the normal African green monkey kidney epithelial (Vero) cell line and using MTT assay.

Results: Sabinene (22.51\%) and terpinene-4-ol (32.33\%) were found to be major components of Z. rhetsa essential oil while limonene (57.94\%) and alpha-phelladrene (15.54\%) were the major components of $Z$. limonella essential oil. Essential oil from Z. limonella exhibited broad spectrum antibacterial activity. Z. rhetsa and Z. limonella essential oils exhibited moderate antioxidant activity. The essential oil from $Z$. rhetsa possessed the ability to inhibit breast cancer cell (MCF-7 and MDA-MB-231) proliferation and cell viability.

Conclusion: This study suggest that the essential oils from Z. limonella and Z. rhetsa could be applied as safe antibacterial and antioxidant agents for food and have the potential for further development of new anticancer agents.

Keywords: Zanthoxylum rhetsa, Zanthoxylum limonella, GC-MS, antibacterial activity, antioxidant activity, anti-breast cancer activity

\section{Introduction}

Recent trends in the demand of natural products for healthcare are increasing due to side effects of synthetic chemicals medicine and people in developing countries being restricted in their access to essential medicines. Traditional medicines also have recently been promoted as a sustainable alternative for healthcare. Since Thailand is a country in tropical zone where it has variety of medicinal plants, many local plants have been studied for their biological activities. The plant genus Zanthoxylum, which is in the family of Rutaceae, is distributed worldwide (Tshin, 2011). Four species of Zanthoxylum have been reported in Northern Thailand (Suksathan et al., 2009). Two major species of Zanthoxylum found and sold in markets by local people are Z. rhetsa (Roxb.) DC and Z. limonella Alston. The plants have a pleasant odour and local people use the fruit rind as condiment in their indigenous food for flavouring. The fruit rind contains a mixture of volatile aroma compounds (Supabphol and Tangjitjareonkun, 2014). $Z$. rhetsa has long been used for medicinal uses as aromatic, astringent, antimicrobial, antiseptic and antidiabetic agent, as 
well as used to treat inflammatory dermatosis, cholera, rheumatism, and toothache (Lalitharani et al., 2010; Reddy and Jose, 2011). Z. limonella has been used as spice in traditional Thai food and used in traditional medicine. Its essential oils has anti-inflammatory, cytotoxic, antifungal, antibacterial and anesthetic properties (Nanasombat and Wimuttigosol, 2011). A previous study showed that sabinene (42.7\%) and limonene (39.1\%) were major components of Z. limonella fruit essential oil (Tangjitjareonkun et al., 2012a). A recent study showed that the major constituents presented in Z. rhetsa fruit essential oil were terpinen-4-ol (25.43\%), sabinene (16.50\%) and beta-pinene (10.40\%) (Naik et al., 2015). The fruits are edible and widely used in traditional medicine for their analgesic, anticonvulsant, anthelmintic, anti-inflammatory, antimicrobial, antinociceptive, antioxidant, antiparasitic and antitumor properties (Patiño et al., 2012).

Several reports are available on the composition and biological activity of the Zanthoxylum essential oils (Misra et al., 2013; Naik et al., 2015; Tangjitjareonkun et al., 2012a). However, composition differs according to geographical and environmental conditions. To provide scientific proof of their medicinal use, this present work reported the chemical components of the Z. rhetsa and Z. limonella essential oils collected from the North of Thailand and their antibacterial, antioxidation and anti-cancer activities.

\section{Material and methods \\ Plant material and essential oil preparation}

Fresh fruits of Z. rhetsa (Roxb.) DC were collected from November to December 2015 from Phayao province, Thailand (voucher No. 2559-010). Z. limonella Alston samples were collected in the same period from Chiang Mai province, Thailand (voucher No. 2559-020). They were authenticated and specimen vouchers were deposited at Program in Biotechnology, Faculty of Science, Maejo University, Chiang Mai, Thailand. The fruits were hydrodistilled in a Clevenger-type apparatus for 6 hours. The essential oils were obtained, dried over anhydrous sodium sulphate and stored in a sealed, light protected bottle at $-20^{\circ} \mathrm{C}$ prior to chemical and biological analyses.

\section{Bacterial strains}

The following bacterial strains were obtained from Department of Medical Sciences, Ministry of Public Health, Thailand: Listeria monocytogenes DMST 17303, Bacillus cereus DMST 5040, Staphylococcus aureus DMST 8840, Salmonella Typhi DMST 5784 and Escherichia coli DMST 4212. Pseudomonas aeruginosa, Vibrio parahaemolyticus and Shigella enteritidis group B were obtained and identified from the Program in Biotechnology, Faculty of Science, Maejo University, Chiang Mai, Thailand. All strains were maintained on Brain Heart Infusion Agar (BHA) slant at $4^{\circ} \mathrm{C}$, and were subcultured on fresh agar plate $24 \mathrm{~h}$ before antibacterial assays.

\section{Identification of essential oil components}

Gas chromatography-mass spectrometry (GC-MS) analyses were performed on a Agilent Technology apparatus (GC 6890, USA) equipped with a Hewlett Packard mass selective detector (MS 5973, USA) and HP-5MS $30 \mathrm{~m} \times 0.25 \mathrm{ID} \times 0.25 \mu \mathrm{m}$ film thickness column (HP-5MS, USA). Oven temperature program was set to the following conditions: $70^{\circ} \mathrm{C}(0-3 \mathrm{~min}) ; 70-188^{\circ} \mathrm{C}\left(3^{\circ} \mathrm{C} / \mathrm{min}\right) ; 188-280^{\circ} \mathrm{C}\left(20^{\circ} \mathrm{C} / \mathrm{min}\right) ; 280^{\circ} \mathrm{C}(3 \mathrm{~min})$, carrier gas: helium; gas flow rate: $1 \mathrm{~mL} / \mathrm{min}$; injection volume $1 \mu \mathrm{L}(10 \mu \mathrm{L}$ of essential oil was diluted with $490 \mu \mathrm{L}$ dichloromethane). MS was connected to GC through transfer line which set the temperature at $150^{\circ} \mathrm{C}$, and ion source temperature was $230^{\circ} \mathrm{C}$. Identification of compound was confirmed by Wiley 275 and NIST98 library.

\section{Minimum inhibitory concentration (MIC) and minimum bactericidal concentration (MBC) determination}

The MIC and MBC were determined by the broth dilution method described by the Clinical and Laboratory Standards Institute (CLSI) (Institute, 2014). The essential oils were first dissolved in dimethyl sulfoxide (DMSO) (Sigma-Aldrich, USA), then in Mueller Hinton Broth (MHB) (Criterion, USA) to the highest dilution of $512 \mathrm{mg} / \mathrm{mL}$. Then serial two-fold dilutions were performed in 96-well microplate at a $50 \mu \mathrm{L}$ final volume per well. The bacterial inoculum was adjusted to 0.5 McFarland Standard and diluted 100 times in MHB. Fifty microliter of bacterial suspension was added to each well. Tetracycline (Pacific Science, Thailand) was used as positive control. MHB culture media and DMSO were used as negative control. This experiment was carried out in triplicate. The microplate was incubated at $37^{\circ} \mathrm{C}$ for $24 \mathrm{~h}$ and examined for the growth of bacteria. The MIC is defined as the lowest concentration of the essential oil at which the bacteria did not demonstrate visible growth. The MBC was performed by inoculating 10 $\mu \mathrm{L}$ of each MIC tested well with no bacterial growth on BHA plates. The MBC was defined as the lowest concentration of the essential oil which gave no viable cells on the BHA plates.

\section{DPPH radical scavenging activity}

DPPH assay is well known in natural product studies (Fukumoto and Mazza, 2000). DPPH is a stable free radical which is purple in color. It will change its color to pale yellow when free radicals were scavenged by antioxidant compounds which can be determined by spectrophotometer. A DPPH (Sigma-Aldrich, Germany) solution 
was prepared at a concentration of $0.2 \mathrm{mM}$ in methanol. For antioxidant evaluation, $2 \mathrm{~mL}$ of DPPH solution was mixed with $1 \mathrm{~mL}$ of different concentrations of the essential oils in methanol. After $30 \mathrm{~min}$ of incubation in the dark at room temperature, the absorbance was measured at a wavelength of $517 \mathrm{~nm}$. Tocopherol (Fluka, Switzerland) and betacarotene (Sigma, Germany) were used as standard. Percentage of inhibition was calculated using following equation: \% inhibition $\left.=\left(\left(\mathrm{A}_{\text {blank }}-\mathrm{A}_{\text {sample }}\right) / \mathrm{A}_{\text {blank }}\right)\right) \mathrm{x} 100$. The antioxidant activity was calculated as $\mathrm{IC}_{50}$ where $\mathrm{IC}_{50}$ is concentration of essential oil that shows $50 \%$ of $\mathrm{DPPH}$ inhibition. The larger the antioxidant capacity, the lower $\mathrm{IC}_{50}$ will be observed.

\section{ABTS radical scavenging activity}

Quantitative determination of ABTS assay is based on reaction of ABTS free radical which is reactive towards antioxidants and changes its color from deep blue to colorless. ABTS (Sigma-Aldrich, Germany) stock solution was prepared by mixing $7 \mathrm{mM}$ ABTS solution with $2.45 \mathrm{mM}$ potassium persulfate (Ajax Finechem, Australia) solution at the ratio of 8:12 and kept in the dark for 16-18 hours. The working solution was prepared by diluting the stock solution with ethanol until the absorbance at $750 \mathrm{~nm}$ was $0.7 \pm 0.2$. Then $200 \mu \mathrm{L}$ of sample was mixed with $1,800 \mu \mathrm{L}$ of working ABTS solution and the reaction tube was incubated in the dark for $5 \mathrm{~min}$. The absorbance was measured at the wavelength of $750 \mathrm{~nm}$. Trolox (Sigma-Aldrich, China) was used as a standard. Percentage of inhibition was calculated using following equation: $\left.\left(\left(\mathrm{A}_{\text {blank }}-\mathrm{A}_{\text {sample }}\right) / \mathrm{A}_{\text {blank }}\right)\right) \mathrm{x} 100$. The antioxidant activity was expressed as Trolox equivalent antioxidant activity (TEAC).

\section{Cytotoxicity and anticancer assay Cell culture}

African green monkey kidney epithelial Vero cells were obtained from Professor Sukhathida Ubol, Faculty of Sciences, Mahidol University, Thailand and breast cancer MCF-7 and MDA-MB-231 cell lines were provided by Professor Shaun McColl, The University of Adelaide, South Australia. Vero cells were grown in Dulbecco's Modified Eagle Medium (DMEM) while MCF-7 and MDA-MB-231 cell lines were cultured in Roswell Park Memorial Institute 1640 (RPMI1640) (Gibco-BRL, NY) at $37^{\circ} \mathrm{C}$ in a $5 \% \mathrm{CO}_{2}$ atmosphere. The medium was supplemented with $10 \%$ fetal bovine serum (FBS), 100 units penicillin and $100 \mu \mathrm{g} / \mathrm{mL}$ streptomycin/mL. (DMEM, RPMI 1640, FBS and penicillin/streptomycin; Gibco-BRL Biochemicals, Grand Island, NY, USA).

\section{Determination of cell viability by 3-(4, 5-dimethylthiazol-2-yl)-2, 5 diphenyltetrazolium bromide assay}

In vitro cytotoxic activity of the essential oils obtained from $Z$. rhetsa and Z. limonella was tested by 3-(4, 5dimethylthiazol-2-yl)-2, 5-diphenyltetrazolium bromide (MTT) assay in Vero, MCF-7 and MDA-MB-231 cell lines. Cell suspension in growth medium of $200 \mu \mathrm{L}\left(2.5 \times 10^{5}\right.$ cells $\left./ \mathrm{mL}\right)$ was seeded into a well in a 96 -well microtiter plate and cultured for 16-18 h. The cells were washed once with PBS and treated with $1 \%$ DMSO-containing medium without sample and various concentrations of the essential oils diluted in the medium for 1 or $24 \mathrm{~h}$. The essential oils were removed carefully and cells were washed with PBS. MTT reagent $(5 \mathrm{mg} / \mathrm{mL}), 50 \mu \mathrm{L}$, was added into a well and the plate was incubated for $1 \mathrm{~h}$ in $5 \% \mathrm{CO}_{2}$ incubator. After incubation, $150 \mu \mathrm{L}$ of solubilising agent DMSO was added to each well and mixed well. Presence of viable cells was determined by the formation of formazan crystal visualized by development of purple color in the well. The plate was then measured for optical density (OD) by spectrophotometer at wavelength of $570 \mathrm{~nm}$. Percentage of cell viability was calculated (Cell viability $(\%)=$ sample $\mathrm{OD} /$ control OD $\mathrm{x}$ 100). The concentration required for $50 \%$ inhibition $\left(\mathrm{IC}_{50}\right)$ of cell viability was analysed by GraphPad Prism 6.0 software (San Diego, CA, USA).

\section{Statistical analysis}

All experiments were carried out in triplicate. Data were expressed as mean \pm standard deviation (SD) or standard of the mean (SEM). The significant differences between groups were analyzed by unpaired student's t-test. $p$ values less than 0.05 were considered statistically significant.

\section{Results}

Essential oils of Z. rhetsa and Z. limonella fruits were obtained by hydrodistillation. The essential oils were analysed for their compositions by GC-MS. The results are shown in Table 1. Z. rhetsa essential oil contained a mixture of 30 chemical components. Terpinen-4-ol and sabinene were major components (32.33 and 22.51\%) followed by gamma-terpinene, decyl aldehyde and octanal (7.97, 5.97 and 5.35\%). Z. limonella essential oil consisted of 21 components. Limonene and alpha-phellandrene were major components (57.94 and 15.54\%) followed by trans-betaocimene $(8.04 \%)$. 
Table 1: Essential oils chemical compositions from fruit of Z. rhetsa and Z. limonella

\begin{tabular}{|c|c|c|c|}
\hline \multirow[t]{2}{*}{$\mathbf{R T}^{\mathbf{a}}$} & \multirow[t]{2}{*}{ Compound } & \multicolumn{2}{|c|}{$\begin{array}{c}\text { Peak area. } \boldsymbol{\%}^{\mathbf{b}} \\
\text { (Data from other authors are included in brackets for comparisons) }\end{array}$} \\
\hline & & Z. rhetsa & Z. limonella \\
\hline 3.95 & Alpha-thujene & $\mathbf{0 . 6 1}\left(0.74^{\mathrm{d}}\right)$ & 0.09 \\
\hline 4.10 & Alpha-pinene & $0.68\left(3.87^{\mathrm{c}}, 4.33^{\mathrm{d}}\right)$ & 2.86 \\
\hline 5.02 & Sabinene & $22.51\left(47.12^{\mathrm{c}}, 16.50^{\mathrm{d}}\right)$ & $\mathbf{0 . 2 2}\left(9.13^{\mathrm{e}}, 42.73^{\mathrm{f}}\right)$ \\
\hline 5.08 & 1-beta-pinene & $\mathbf{0 . 8 2}\left(3.87^{\mathrm{c}}, 10.40^{\mathrm{d}}\right)$ & - \\
\hline 5.39 & beta-Myrcene & $1.18\left(0.74^{\mathrm{c}}, 0.68^{\mathrm{d}}\right)$ & 3.05 \\
\hline 5.76 & Octanal & 5.35 & - \\
\hline 5.81 & Alpha-phellandrene & $-\left(0.48^{c}\right)$ & $15.54\left(0.7^{f}\right)$ \\
\hline 5.93 & Delta, 3-carene & $-\left(0.05^{\mathrm{c}}\right)$ & $0.24\left(2.70^{f}\right)$ \\
\hline 6.13 & Alpha-terpinene & $4.40\left(3.45^{\mathrm{c}}\right)$ & - \\
\hline 6.38 & Para-cymene & $2.65\left(3.08^{\mathrm{c}}, 2.45^{\mathrm{d}}\right)$ & - \\
\hline 6.57 & 1, 8-cineole & 1.90 & - \\
\hline 6.59 & Limonene & $-\left(4.06^{\mathrm{c}}\right)$ & $\mathbf{5 7 . 9 4}\left(31.09^{\mathrm{e}}, 39.05^{\mathrm{f}}\right)$ \\
\hline 6.76 & Cis-ocimene & - & 1.57 \\
\hline 7.10 & Trans-beta-ocimene & $-\left(0.42^{c}\right)$ & $8.04\left(0.1^{f}\right)$ \\
\hline 7.45 & Gamma-terpinene & $7.97\left(3.64^{c}, 5.64^{d}\right)$ & - \\
\hline 7.81 & Trans-sabinene & $\mathbf{0 . 2 0}\left(0.34^{\mathrm{d}}\right)$ & - \\
\hline 7.99 & 1-octanol & $2.44\left(0.67^{\mathrm{c}}, 0.20^{\mathrm{d}}\right)$ & 0.25 \\
\hline 8.41 & Terpinolene & $1.84\left(0.71^{\mathrm{c}}, 1.48^{\mathrm{d}}\right)$ & 0.12 \\
\hline 8.97 & Linalool & $1.41\left(0.76^{\mathrm{c}}, 3.25^{\mathrm{d}}\right)$ & 3.24 \\
\hline 9.75 & 2-cyclohexen-1-ol & 1.48 & 0.34 \\
\hline 10.46 & 1-terpineol & 0.99 & - \\
\hline 10.71 & Cyclohexene & 0.17 & - \\
\hline 12.05 & Terpinen-4-ol & $32.33\left(6.61^{c}, 25.43^{d}\right)$ & $0.27\left(13.94^{e}, 5.40^{f}\right)$ \\
\hline 12.52 & 1-alpha-terpineol & $\mathbf{2 . 0 5}\left(7.73^{\mathrm{c}}, 7.63^{\mathrm{d}}\right)$ & 1.65 \\
\hline 12.65 & Cis-piperitol & 0.42 & - \\
\hline 12.97 & Decyl aldehyde & $\mathbf{5 . 9 7}\left(0.36^{\mathrm{d}}\right)$ & 1.28 \\
\hline 13.20 & Trans-piperitol & 0.66 & - \\
\hline 13.24 & Octyl acetate & - & 1.50 \\
\hline 15.88 & Cyclooctane & 0.45 & - \\
\hline 15.94 & 3-hexyne-2, 5-diol & 0.28 & - \\
\hline 16.63 & 2-undecanone & - & 0.60 \\
\hline 20.38 & Lavandulyl acetate & - & 0.75 \\
\hline 21.34 & Dodecanal & 0.19 & - \\
\hline 21.54 & Beta-caryophyllene & $\mathbf{0 . 1 7}\left(0.63^{\mathrm{c}}\right)$ & - \\
\hline 24.04 & Germacrene & 0.20 & - \\
\hline 24.85 & 2-tridecanone & - & 0.10 \\
\hline 25.76 & Delta-cadinene & $\mathbf{0 . 1 1}\left(0.33^{\mathrm{c}}\right)$ & - \\
\hline 30.85 & Alpha-cadinol & 0.19 & - \\
\hline 46.53 & 9-octadecenamide & 0.40 & 0.35 \\
\hline
\end{tabular}

${ }^{a}$ RT, (Retention time, min); ${ }^{b}$ peak area obtained by GC-MS of the present study; (Jirovetz et al., 1998); (Naik et al.,

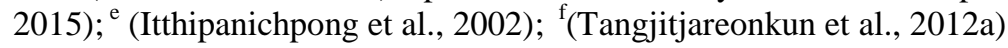

The essential oils were tested for antibacterial susceptibility against pathogenic bacteria by microdilution method (Table 2). Both essential oil showed broad spectrum antibacterial activity. Z. limonella essential oil presented lower MIC/MBC values of $8-128 / 8-128 \mathrm{mg} / \mathrm{mL}$ while $Z$. rhetsa essential oil showed higher MIC/MBC values of $256 / 256 \mathrm{mg} / \mathrm{mL}$. Z. limonella essential oil showed strongest antibacterial activity $(4-8 / 8 \mathrm{mg} / \mathrm{mL})$ against $B$. cereus, $S$. aureus and E. coli.

Table 2: Essential oil susceptibility test by microdilution

\begin{tabular}{lccc}
\hline \multicolumn{1}{c}{ Bacteria } & \multicolumn{2}{c}{ MIC/MBC (mg/mL) } \\
& Z. rhetsa & Z. limonella & Tetracycline \\
\hline Gram positive bacteria & & & \\
Listeria monocytogenes DMST 17303 & $256 / 256$ & $64 / 64$ & $0.002 / 0.004$ \\
Bacillus cereus DMST 5040 & $256 / 256$ & $8 / 8$ & $0.004 / 0.008$ \\
Staphylococcus aureus DMST 8840 & $256 / 256$ & $4 / 8$ & $0.001 / 0.004$ \\
Gram negative bacteria & & & \\
Salmonella Typhi DMST 5784 & & & \\
Shigella enteritidis group B & $256 / 256$ & $8 / 8$ & $0.016 / 0.016$ \\
Escherichia coli DMST 4212 & $256 / 256$ & $128 / 128$ & $0.016 / 0.016$ \\
\hline 15 & $256 / 256$ & $8 / 8$ & $0.002 / 0.008$ \\
\hline
\end{tabular}




\begin{tabular}{llll}
\hline Pseudomonas aeruginosa & $256 / 256$ & $16 / 64$ & $0.032 / 0.064$ \\
Vibrio parahaemolyticus & $256 / 256$ & $16 / 16$ & $0.008 / 0.016$
\end{tabular}

The DPPH and ABTS radical scavenging activities of essential oils from Z. rhetsa and Z. limonella fruits are shown in Table 3. Both essential oils demonstrated similar DPPH (25 and $24 \mathrm{mg} / \mathrm{mL}$, respectively) and ABTS radical scavenging activities (16.35 and $13.6 \mathrm{mg} / \mathrm{mL}$, respectively).

Table 3: DPPH and ABTS of the Z. rhetsa and Z. limonella essential oil

\begin{tabular}{lll}
\hline Essential oil & $\mathbf{I C}_{\mathbf{5 0}}(\mathbf{m g} / \mathbf{m L})$ & TEAC $(\boldsymbol{\mu M})$ \\
\hline Z. rhetsa & $25 \pm 5$ & $16.35 \pm 0.04$ \\
Z. limonella & $24 \pm 3$ & $13.6 \pm 0.2$ \\
Tocopherol & $3.67 \pm 0.09$ & $0.3 \pm 0.2$ \\
Beta-carotene & $108 \pm 5$ & $108.7 \pm 0.2$ \\
\hline
\end{tabular}

$\mathrm{IC}_{50}$ : the concentration of essential oil at DPPH radical scavenging activity 50\%; TEAC: Trolox equivalents antioxidant capacity

The essential oils were initially tested for their cytoxicity with Vero cells as well as breast cancer MCF-7 and MDA-MB-231 cell lines. After 24 hours exposure, the cell viability assay demonstrated that $\mathrm{IC}_{50}$ of the $Z$. rhetsa and $Z$. limonella essential oils tested with all cell lines were less than $0.82 \mu \mathrm{g} / \mathrm{mL}$. According to the American National Cancer Institute guidelines that set the limit of activity for crude extract at $\mathrm{IC}_{50}$ of proliferation less than $30 \mathrm{mg} / \mathrm{ml}$ (Suffness and Pezzuto 1990), the extracts were tested for anti-cancer activity in MCF-7 and MDA-MB-231 and normal Vero cell lines. As shown in Table 4, after 1 hour of exposure to the essential oils, MTT assay indicated that the concentrations at which $50 \%$ cells death occur $\left(\mathrm{IC}_{50}\right)$ of $Z$. rhetsa extract tested in Vero cells $(3.75 \pm 0.72 \mu \mathrm{g} / \mathrm{mL})$ was significantly 2 times greater than those tested in MCF-7 $(1.98 \pm 0.23 \mu \mathrm{g} / \mathrm{mL})$ and MDA-MB-231 cells $(1.96 \pm 0.24 \mu \mathrm{g} / \mathrm{mL})$ $(p<0.0001)$, while there is no significant difference of the $\mathrm{IC}_{50}$ of $\mathrm{Z}$. Limonella extract tested between those in Vero, and in MCF-7 or MDA-MB-231 cells $(p>0.5)$.

Table 4: Inhibitory concentration $50\left(\mathrm{IC}_{50}\right)$ of the Z. rhetsa and Z. limonella essential oil tested in Vero, MCF-7 and MDA-MB-231 cells

\begin{tabular}{llcc}
\hline Essential oil & \multicolumn{3}{c}{ IC $_{\mathbf{5 0}}(\mathbf{M e a n} \pm \mathbf{S D})(\boldsymbol{\mu g} / \mathbf{m L})$} \\
\cline { 2 - 4 } & Vero cells & MCF-7 cells & MDA-MB-231 cells \\
\hline Z. rhetsa & $3.75 \pm 0.72$ & $1.98 \pm 0.23$ & $1.96 \pm 0.24$ \\
Z. limonella & $8.53 \pm 2.17$ & $5.40 \pm 1.37$ & $3.80 \pm 1.03$ \\
\hline $\mathrm{IC}_{50} \cdot$ half-maximal inhibitory concentration & &
\end{tabular}

\section{Discussion}

In the present study, the chemical compositions of essential oils obtained from Z. rhetsa and Z. limonella was investigated. It was found that terpinene and sabinene (32.33 and $22.51 \%$, respectively) were the major components in Z. rhetsa while the major components in Z. limonella were limonene and alpha-phellandrene (57.94 and $15.54 \%$, respectively). Components from $Z$. rhetsa differ from two reports where the plant material was collected from India (Jirovetz et al., 1998; Naik et al., 2015). Sabinene (47.12\%) was found to be a major component from Z. rhetsa seed (Jirovetz et al., 1998) but terpinen-4-ol, sabinene and 1-beta-pinene (25.43, 16.50 and 10.40\%, respectively) were found to be the major components (Naik et al., 2015). Components from Z. limonella from this study differ from 2 other reports even though the plant was collected from Thailand (Itthipanichpong et al., 2002; Tangjitjareonkun et al., 2012a). From this study, limonene was found to be the major component from Z. limonella (57.94\%) which was almost 2 times higher than that was reported from another study (31.09\%) (Itthipanichpong et al., 2002). This study is also in contrast with Tangjitjareonkun et al, (2012) where it was reported that sabinene was the major component followed by limonene (42.73 and 39.05\%). In a given species of plant, variation of chemical compositions and content may occur as a result of genetic or environmental factors such as age of plant, season, phase of plant development, geographical location and bioclimate distribution (Eiter et al., 2010; ElHadj Ali et al., 2010; Nezhadali et al., 2014; Zouari et al., 2012).

Z. rhetsa and Z. limonella have been reported with uses as spices and medicine for infectious diseases (Patiño et al., 2012). The results from this study showed that essential oils from both species had broad spectrum antibacterial activity to Gram positive and negative bacteria. This is in accordance with other studies that showed broad spectrum antibacterial activity from these oils (Naik et al., 2015; Supabphol and Tangjitjareonkun, 2014; Tangjitjareonkun et al., 2012a). In this study, Z. rhetsa essential oil showed similar MIC/MBC level against all tested bacteria at 256/256 $\mathrm{mg} / \mathrm{mL}$ while the essential oil from $Z$. limonella showed greater antibacterial activity with variable MIC/MBC levels ranging from 4-128/8-128. 
A previous study (Naik et al., 2015) reported antibacterial activity of Z. rhetsa oil, fractions and pure compound (terpinen-4-ol) against 3 bacteria: S. aureus ATCC 6538a, E. coli ATCC 8739 and Klebsiella pneumonia. The essential oil showed greater antibacterial activity against Gram positive bacteria (S. aureus) than Gram negative bacteria ( $E$. coli and $K$. pneumonia). The MIC level of the crude essential oil and terpinen-4-ol against $S$. aureus were $35 \mu \mathrm{g} / \mathrm{mL}$ while the MIC levels of the fractions were $70-140 \mu \mathrm{g} / \mathrm{mL}$. This suggested a synergistic effect of active constituents contained in the crude oil. In this study, terpinen-4-ol was the major component in Z. rhetsa oil. It is suggested that purified components and the synergistic effect of the components should be further investigated.

A previous study (Tangjitjareonkun et al., 2012a) presented antibacterial activity of from fruit of Z. limonella against 4 bacteria; B. subtilis ATCC 6633, S. aureus, E. coli ATCC 25922 and P. aeruginosa ATCC 27853. The crude oil had stronger antibacterial activity than the pure compounds (sabinene and terpinen-4-ol) but limonene had no antibacterial activity. The results of this study showed limonene and alpha-phelandrene as major components (57.94 and 15.54\%). Supportive data from Iscan et al (2012) (Iscan et al., 2012) showed that alpha-phellandrene and its biotransformation metabolites had antibacterial activity. It has been suggested that alpha-phellandrene acts as active antibacterial agent. In addition, a metabolite from alpha-phellandrene (5-p-menthene-1,2-diol) gave stronger antibacterial activity than phellandrene. This suggested that not only active components and synergistic effects should be investigated further, but also the chemical or biological modification of the active compounds should be further investigated to study the subsequent antibacterial activity.

The essential oils from Z. rhetsa and Z. limonella presented similar antioxidant activity (Table 3). A previous study (Nanasombat and Wimuttigosol, 2011) reported strong antioxidant activity of the fruit of Z. limonella essential oil with $\mathrm{IC}_{50}$ value of $5.66 \mathrm{mg} / \mathrm{mL}$. Tangjitjareonkun, Supabphol, Cavasiri (2012a) (Tangjitjareonkun et al., 2012b) reported DPPH antioxidant assay of $Z$. limonella fruit essential oil with $\mathrm{IC}_{50}$ value of 5,764 $\mu \mathrm{g} / \mathrm{mL}$ and the TEAC value was $7.1 \mu \mathrm{M}$. They showed mixture compounds of $Z$. limonella fruit essential oil with DPPH scavenging effect on thin layer chromatography (TLC).

The cell viability assays indicated cytotoxicity of these essential oils in all cell lines that was relatively selective to the breast cancer cells. The inhibitory effect of $Z$. rhetsa essential oil on cell viability of breast cancer cells suggested potential ability of the essential oil to inhibit cancer cell proliferation and cell survival. A previous study reported cytotoxic effect of $Z$. rhetsa bark constituents against melanoma cancer cells (B16-F10) but is non-toxic to normal skin cell lines and suggested that lignans and alkaloids were responsible for the cytotoxic properties (Santhanam et al., 2016). Another Zanthoxylum species (Z. Schinifolium) was also reported to be toxic to HepG2 human hepatoma cell lines (Paik et al., 2005). However, in this study, the Z. rhetsa essential oil showed the relatively lower selective ability to cancer cells than those observed in the previous studies possibly due to differences in the extraction methods, parts of plant and chemical compositions in the extracts. Additionally, the anti-cancer activities of the essential oils should be further clarified in relation to standard cancer drugs such as a doxorubicin and mechanisms underlying the potential anti-cancer activities is required more investigation.

The findings of this study suggest the possibility of these essential oils as safe antibacterial and antioxidant agents for food and have the potential for further development of new anticancer agents. More study on active components with their synergistic effects should be undertaken. The area of investigation of the chemical or biological modification of active compounds to enhance biological effects and mechanism of the active compounds on those biological evaluations is also in need of further work.

Conflict of interest statement: We declare that we have no conflict of interest.

Acknowledgments: This work was supported by Maejo University research fund (Grant No. MJU 1-58-069) and Naresuan University research fund (Grant No. R2559B067).

\section{References}

1. Eiter LC, Fadamiro H, Setzer WN. (2010). Seasonal variation in the leaf essential oil composition of Zanthoxylum clava-herculis growing in Huntsville, Alabama. Natural Product Communications 5(3):457-460.

2. ElHadj Ali IB, Zaouali Y, Bejaoui A, Boussaid M. (2010). Variation of the chemical composition of essential oils in Tunisian populations of Thymus algeriensis Boiss. et Reut. (Lamiaceae) and implication for conservation. Chemistry and Biodiversity 7(5):1276-1289.

3. Fukumoto L, Mazza G. (2000). Assessing antioxidant and pro-oxidant activities of phenolic compounds. Journal of Agricultural and Food Chemistry 48(8):3597-3604.

4. Institute CaLS. (2014). Performance standards for antimicrobial susceptibility testing; 24th informational supplement. CLSI document M100-S24. Wayne, PA: Clinical and Laboratory Standards Institute.

5. Iscan G, Kirimer N, Demirci F, Demirci B, Noma Y, Baser KH. (2012). Biotransformation of (-)-(R)-alphaphellandrene: antimicrobial activity of its major metabolite. Chemistry and Biodiversity 9(8):1525-1532.

6. Itthipanichpong C, Ruangrungsi N, Pattanaautsahakit C. (2002). Chemical compositions and pharmacological effects of essential oil from the fruit of Zanthoxylum limonella. Journal of the Medical Association of Thailand 85 Suppl 1:S344-354. 
7. Jirovetz L, Buchbauer G, Shafi M, Saidutty A. (1998). Analysis of the aroma compounds of the essential oil of seeds of the spice plant Zanthoxylum rhetsa from southern India. Zeitschrift für Lebensmittel-Untersuchung und -Forschung 206(3):228-229.

8. Lalitharani S, Mohan VR, Regini GS. (2010). GC-MS analysis of ethanolic extract of Zanthoxylum rhetsa (roxb.) dc spines. Journal of Herbal Medicine Toxicology 4(4):191-192.

9. Misra LN, Wouatsa NA, Kumar S, Venkatesh Kumar R, Tchoumbougnang F. (2013). Antibacterial, cytotoxic activities and chemical composition of fruits of two Cameroonian Zanthoxylum species. Journal of Ethnopharmacology 148(1):74-80.

10. Naik R, Shakya A, Khalaf N, Abuhamdah S, Oriquat G, Marraqa A. (2015). GC-MS Analysis and Biological Evaluation of Essential Oil of Zanthoxylum rhesta (Roxb.) DC Pericarp. Jordan Journal of Pharmaceutical Sciences 8(3):181-192.

11. Nanasombat S, Wimuttigosol P. (2011). Antimicrobial and antioxidant activity of spice essential oils. Food Science and Biotechnology 20(1):45-53.

12. Nezhadali A, Navabi M, Rajabian M, Akbarpour M, Pourali P, Amini F. (2014). Chemical variation of leaf of essential oil on different stages of plant growth and in vitro antibacterial activity of Thymus vulgaris Laminaceae, from Iran. Beni-Suef University Journal of Basic and Applied Sciences 3(2):87-92.

13. Paik SY, Koh KH, Beak SM, Paek SH, Kim JA. (2005). The essential oils from Zanthoxylum schinifolium pericarp induce apoptosis of HepG2 human hepatoma cells through increased production of reactive oxygen species. Biological and Pharmaceutical Bulletin 28(5):802-807.

14. Patiño O, Prieto J, Cuca L. (2012). Bioactive Compounds in Phytomedicine: InTech.

15. Reddy LJ, Jose B. (2011). Statistical analysis of the antibacterial activity of Zanthoxylum rhetsa seed essential oil. Journal of Chemical Pharmaceutical Research 3(1):440-444.

16. Santhanam RK, Ahmad S, Abas F, Safinar Ismail I, Rukayadi Y, Tayyab Akhtar M, Shaari K. (2016). Bioactive constituents of Zanthoxylum rhetsa bark and its cytotoxic potential against B16-F10 melanoma cancer and normal human dermal fibroblast (HDF) cell lines. Molecules 21(6), 652.

17. Suffness M, Pezzuto JM. (1990) Assays related to cancer drug discovery. In: Hostettmann K (ed). Methods in Plant Biochemistry: Assays for Bioactivity, Vol. 6, Academic Press, London. 71-133.

18. Suksathan R, Trisonthi C, Trisonthi P, Wangpakapattanawong P. (2009). Notes on spice plants in the genus Zanthoxylum (Rutaceae) in northern Thailand. Thai Forest Bulletin (special issue):197-204.

19. Supabphol R, Tangjitjareonkun J. (2014). Chemical constituents and biological activities of Zanthoxylum limonella (Rutaceae): A Review Tropical Journal of Pharmaceutical Research 13(12):2119-2130.

20. Tangjitjareonkun J, Chavasiri W, Thunyaharn S, Yompakdee C. (2012a). Bactericidal effects and time-kill studies of the essential oil from the fruits of Zanthoxylum limonella on multi-drug resistant bacteria. Journal of Essential Oil Research 4(4):363-370.

21. Tangjitjareonkun J, Supabphol R, Chavasiri W. (2012b). Antioxidant effect of Zanthoxylum limonella Alston. Journal of Medicinal Plants Research 6(8):1407-1414.

22. Tshin R. (2011). Zanthoxylum: A low-profile Asian crop with great potential. ECHO Asia Notes, A reginal supplement to ECHO Development Notes(8).

23. Zouari N, Ayadi I, Fakhfakh N, Rebai A, Zouari S. (2012). Variation of chemical composition of essential oils in wild populations of Thymus algeriensis Boiss. et Reut., a North African endemic species. Lipids in Health and Disease 11:28. 